\title{
Aplikasi Guided Imagery Terhadap Nyeri Pada Pasien Gastritis Di Wilayah Kerja Puskesmas Cijedil Kabupaten Cianjur
}

\author{
Novi Noerasyah Jamil ${ }^{1}$, Sri Kurnia Dewi ${ }^{2}$ \\ ${ }^{1}$ Universitas Muhammadiyah Sukabumi \\ ${ }^{2}$ Universitas Muhammadiyah Sukabumi \\ ${ }^{3}$ Universitas Muhammadiyah Sukabumi \\ E-mail: novinoerasyah@ummi.ac.id, srikurniadewi484@ummi.ac.id
}

\begin{abstract}
Abstrak
Gastritis adalah peradangan mukosa lambung yang menyebabkan nyeri akut sehingga dapat mengganggu aktivitas sehari-hari orang yang mengalaminya. Nyeri akut adalah pengalaman sensori dan emosional yang tidak menyenangkan akibat kerusakan jaringan yang aktual dan potensial. Tujuan Penelitian ini Untuk mengurangi nyeri dilakukan terapi guided imagery. Penelitian ini menggunakan metode studi kasus. Partisipan yang diambil sebanyak satu responden yaitu klien yang mengalami penyakit gastritis dengan masalah keperawatan nyeri akut. Hasil Penelitian menunjukan klien mengalami penurunan skala nyeri yang awalnya mendapat skala 5 menjadi skala 3. Berdasarkan hasil tersebut dapat disimpulkan bahwa terapi guided imagery adanya pengaruh dalam penerunan skala nyeri
\end{abstract}

Kata kunci: gastritis, terapi guided imagery, nyeri akut

\begin{abstract}
Gastritis is an inflammation of the gastric mucosa that causes acute pain so that it can interfere with the daily activities of people who experience it. Acute pain is an unpleasant sensory and emotional experience resulting from actual and potential tissue damage. The purpose of this study is to reduce pain guided imagery therapy. This research uses case study method. Participants were taken as many as one respondent, namely clients who experienced gastritis with acute pain nursing problems. The results showed that the client experienced a decrease in the pain scale which initially received a scale of 5 to 3 . Based on these results, it can be concluded that guided imagery therapy has an influence on reducing the pain scale.
\end{abstract}

Keywords: gastritis, guided imagery therapy, acute pain

\section{Pendahuluan}

Guided imagery merupakan salah satu teknik distraksi nyeri yang bisa digunakan dalam penanganan nyeri, menurunkan tekanan darah, menurunkan kadar kolesterol, glukosa dan meningkatkan aktivitas sel (Naparstek, 2017). Dua jenis gastritis yang sering terjadi adalah gastritis superfisial akut dan gastritis atropik kronis (Huda \& Kusumah, 2015). Penyebab dari penyakit gastritis menurut Dermawan \& Rahayuningsih (2010) antara lain stress, alkohol dan rokok, obat - obatan anti inflamasi non-steroid seperti aspirin, makanan merangsang (pedas, panas, asam/alkali kuat), dan infeksi bakteri Helicobacter phylori. Guided imagery merupakan suatu teknik dengan menganjurkan pasien untuk mengalihkan pikirannya terhadap sesuatu yang indah sesuai dengan instruksi dari perawat sehingga nyeri yang dialami oleh pasien akan hilang atau berkurang. Salah satu penelitian yang meneliti tentang guided imagery yang dilakukan oleh Sumariadi (2021). Dalam penelitiannya dilakukan tindakan guided imagery pada pasien gastritis dan disimpulkan bahwa tindakan guided imagery berpengaruh terhadap penurunan rasa nyeri pada pasien gastritis.

\section{Metode}

Penelitian ini menggunakan penelitian deskriptif kualitatif dengan strategi studi kasus dan bertujuan untuk mengetahui efektifitas guided imagery mengurangi nyeri pada pasien gastritis. Pendekatan yang digunakan adalah asuhan keperawatan yang meliputi pengkajian keperawatan, 
diagnosis keperawatan, perencanaan keperawatan, implementasi keperawatan dan evaluasi keperawatan.

\section{Hasil}

Peneliti mengumpulkan informasi secara sistematis mengenai klien dengan pendekatan teoritis yang terkait dimulai dari keluhan utama, riwayat kesehatan dan pengkajian fisik klien. Klien mengatakan nyeri pada bagian abdomen pada ulu hati. Nyeri ulu hati terasa seperti ditusuk dan datang tidak menentu, nyeri bertambah ketika makan yang keras-keras. Hal ini sesuai dengan penelitian menurut Sukarmin (2013) manifestasi gastritis yaitu ada rasa tidak nyaman diperut sebelah atas. Klien mengatakan nyeri pada bagian abdomen skala nyeri 5 (1-10) sesuai dengan teori menurut Solehati \& Kosasih (2015) pada skala verbal atau Visual Analog Scale (VAS) untuk mengukur intensitas nyeri digunakan skala rentang 0-10 dan 5-6 termasuk nyeri berat.

Berdasarkan hasil pengkajian dan analisis data dengan data subjektif didapatkan hasil bahwa klien merasakan nyeri pada perut bagian ulu hati dengan skala nyeri 5 (5-10). Sementara itu, data objektif didapatkan klien tampak meringis kesakitan yang menimbulkan diagnosis keperawatan yaitu nyeri akut berhubungan dengan agen pencedera fisiologis.

Dari permasalahan keperawatan yang ada, focus dari studi kasus ini untuk mengatasi nyeri ulu hati. Pada kasus klien intervensi ini dilaksanakan selama tiga kali kunjungan, sesuai Sumariadi, dkk (2021). Implementasi selama tiga kali kunjungan dilakukan dengan memberikan terapi guided imagery setiap jam 13.00 WIB. Hasil evaluasi terdapat kesesuaian antara kasus dengan teori bahwa terdapat pengaruh yang signifikan mengenai adanya penurunan skala nyeri, dari skala 5 menjadi skala 3 selama tiga kali kunjungan berturut-turut.

\section{Simpulan}

Pada pengkajian keperawatan hasil yang didapatkan yakni terjadi nyeri ulu hati terasa seperti ditusuk dan datang tidak menentu, nyeri bertambah ketika makan yang keras-keras dan skala nyeri 5 dari 0-10. Diagnosis keperawatan yang muncul yaitu nyeri akut berhubungan dengan agen pencedera fisiologis. Intervensi terapi guided imagery untuk menurunkan intensitas nyeri dilakukan selama 3 kali kunjungan setiap jam 13.00 WIB. Evaluasi pada hari terakhir klien mengatakan nyeri pada perut bagian ulu hati sudah sedikit menurun skala nyeri $3(0-10)$, setelah dilakukan tindakan guided imagery. Sehingga dapat disimpulkan bahwa terdapat pengaruh yang signifikan mengenai adanya penurunan skala nyeri, dari skala 5 menjadi skala 3 selama tiga kali kunjungan berturut-turut.

\section{DAFTAR PUSTAKA}

Dermawan, D \& Rahayuningsih, T. (2010). Keperawatan medikal bedah sistem pencernaan. Gosyen publising.

Huda, A. N \& Kusumah, H. (2015). NANDA NIC-NOC: Aplikasi Asuhan Keperawatan Berdasarkan Diagnosa Medis. Jilid 2. Medication.

Solehati, T \& Kosasih CE. (2015). Konsep dan aplikasi relaksasi dalam keperawatan maternitas. PT Refika Aditama.

Sukarmin. (2013). Keperawatan Pada Sistem Pencernaan. Pustaka Pelajar.

Sumariadi, S., Simamora, D., Nasution, L., Hidayat, R., \& Sunarti, S. (2021). Efektivitas Penerapan Guided Imagery terhadap Penurunan Rasa Nyeri Pasien Gastritis. Jurnal Penelitian Perawat Profesional, 3(1), 199-206. https://doi.org/10.37287/jppp.v3i1.389 